\title{
ISOLATION, MORPHOLOGY, AND PROTEIN AND GLYCOPROTEIN COMPOSITION OF SYNAPTIC JUNCTIONAL FRACTIONS FROM THE BRAIN OF LOWER VERTEBRATES: ANTIGEN PSD-95 AS A JUNCTIONAL MARKER ${ }^{1}$
}

\author{
M. NIETO-SAMPEDRO, ${ }^{2}$ C. M. BUSSINEAU, AND C. W. COTMAN \\ Department of Psychobiology, University of California, Irvine, California 92717
}

Received September 10, 1981; Revised January 12, 1982; Accepted January 15, 1982

\begin{abstract}
Synaptic junction (SJ) fractions were isolated from the brains of the gray shark, bonito, common frog, several reptiles, and common chicken and compared to those prepared from mammalian brain. All SJ preparations, as judged by electron microscopic analysis, were at least $85 \%$ pure, consisting primarily of postsynaptic densities (PSDs) with or without an overlying plasma membrane and, to a lesser extent, of complete synaptic junctions. Complete junctions were less abundant in preparations from lower vertebrates. The electrophoretic pattern of SJs from different vertebrate species showed considerable conservation of the major protein bands. The most abundant were fibrous proteins, especially tubulins, actin, and the PSD-specific polypeptide with a molecular weight of 52,000 (PSD-52). Glycoproteins capable of binding concanavalin A were present in SJs from all vertebrates; their apparent molecular weight and relative abundance were characteristic of each animal order examined, showing more similarities in species more closely related phylogenetically. Finally, a protein (antigen PSD-95) previously shown to be located specifically in the postsynaptic densities of the mammalian brain was present in all species. The binding of antibody specific to this protein decreased with descending phylogenetic order from mammals to shark. Nonetheless, PSD95 was present in all vertebrate species and appeared to be a general specific marker for PSDs.
\end{abstract}

The brain of lower vertebrates is widely used in the study of synaptogenesis at the anatomical and neurophysiological levels (Jacobson, 1978; Lund, 1978; Horder and Martin, 1978; Edds et al., 1979). However, a description of its subcellular fractionation and the isolation of purified synaptic junctional fractions is not available. Rostas et al. (1979) prepared synaptic plasma membranes (SPMs) and synaptic junctions ( $\mathrm{SJ}_{\mathrm{s}}$ ) from the brain of several mammals and chicken using the iodonitrotetrazolium (INT) method to increase mitochondrial density (Cotman and Taylor, 1972; Davis and Bloom, 1973). This method is probably the fastest available to date to prepare SPM of adequate purity for further subfractionation and was used, as described in this report, for the purification of synaptic plasma membranes and synaptic junctions from the brain of vertebrate species in the most populated phylogenetic levels. Brain tissue from different

\footnotetext{
'We wish to thank Mrs. Ann Kwan for her help in the preparation of samples for electron microscopy. This work was supported by $\mathrm{Na}$ tional Institutes of Health Grant NS 08957 and National Institute of Mental Health Grant MH 19691.

${ }^{2}$ To whom correspondence should be addressed.
}

species gave similar subcellular fractions and SJs of comparable purity as judged by quantitative electron microscopy. The protein composition of the different $\mathrm{SJ}$ was compared by high resolution SDS-polyacrylamide gel electrophoresis and the abundance of common proteins and concanavalin A-binding glycoproteins was determined. Particular attention was given to antigen PSD. 95 , a neuronal protein whose location in mammals is restricted to the postsynaptic density (PSD; Nieto-Sampedro et al., 1981b). Antigen PSD-95 was present in the brain of all vertebrate species examined and its abundance with respect to brain homogenate increased in the subcellular fractions as these became enriched in synaptic junctions. We propose that, as in mammals, PSD-95 is located selectively in the PSD of all vertebrates.

\section{Materials and Methods}

Experimental animals. The different vertebrate phylogenetic levels were represented in this study as follows: order Euselachii, the gray shark (Carcharinus menissorah); order Teleostii, the bonito (Sarda orientalis); order Anura, the common frog (Rana pipiens); order Lacertilia, the western fence lizard (Sceloporus occidentalis), 
the desert iguana (Dipsosaurus dorsalis), the golden tegu (Tupinambis nigropunctatus), and water monitor (Varanus salvator); order Neognathae, the domestic chicken (Gallus domesticus); order Rodentia, the mouse (Mus musculus, strain C57) and the white rat (Rattus norvegicus, var. albinus, strain Sprague-Dawley); order Artyodactyla, the domestic ox (Bos taurus). Marine fish, obtained from local fishermen, were maintained in ice until their brains were processed 2 to $4 \mathrm{hr}$ after capture. Adult reptile brains were the kind gift of the Laboratory of Comparative Physiology of the University of California, Irvine. Frogs were purchased from Dahl Biological (Oakland, CA) and male chickens (17 days old) were from a local farm. Strain C57 mice were the gift of A. M. Frostholm, who bred them from an original stock colony at the Jackson Laboratory (Bar Harbor, ME). Bovine brains were obtained from a local slaughterhouse within 20 to $30 \mathrm{~min}$ of the animal's death, transferred to cold $0.32 \mathrm{M}$ sucrose, and fractionated 2 to $3 \mathrm{hr}$ later.

Subcellular fractionation. Except for fish and oxen, all other animals were killed by decapitation and their brains, rostral to the superior colliculi (mammals and chicken) or the medulla oblongata (all other species), were used for subcellular fractionation by the method of Cotman and Taylor (1972) slightly modified by the use of a concentration of $p$-iodonitrotetrazolium violet (INT) of $1.5 \mathrm{mg} / \mathrm{gm}$ of wet brain tissue (Nieto-Sampedro et al., 1981a). To fractionate amounts of tissue between 0.3 and $3.0 \mathrm{gm}$, discontinuous sucrose density gradients (NietoSampedro et al., 1981a) were made and centrifuged on a Beckman SW 50.1 rotor. The gradients consisted of three $1.1-\mathrm{ml}$ layers of $1.3,1.0$, and $0.8 \mathrm{M}$ sucrose. INT-trealed $\mathrm{P}_{2}$ pellets suspended in 1.4 to $1.5 \mathrm{ml}$ of $0.32 \mathrm{M}$ sucrose were layered on top of the gradient and centrifugation was carried out at $40,000 \mathrm{rpm}\left(150,000 \times \mathrm{g}_{\mathrm{av}}\right)$, at $4^{\circ} \mathrm{C}$, for $1 \mathrm{hr}$. The gradients were fractionated into "myelin" $(0.32-$ 0.8 м sucrose interface); "light SPMs" (0.8-1.0 M sucrose interface); "heavy SPMs" (1.0-1.3 M sucrose interface), and mitochondria (pellet). To prepare purified SJs, "heavy SPMs" suspended in cold $0.32 \mathrm{~m}$ sucrose, $0.2 \mathrm{~mm}$ HEPES buffer, $\mathrm{pH} 7.4$, at a concentration of $4 \mathrm{mg}$ of protein $/ \mathrm{ml}$, were treated with $2 \mathrm{vol}$ of a chilled solution of Triton X-100 $(4 \mathrm{mg} / \mathrm{ml})$ in $1 \mathrm{mM}$ EDTA, 2 mM HEPES buffer, $\mathrm{pH} 7.4$, at 0 to $4^{\circ} \mathrm{C}$ for $10 \mathrm{~min}$. Addition of the detergent solution was slow, dropwise, while swirling the mixture, and the final concentration of Triton X-100 was $0.27 \%(\mathrm{w} / \mathrm{v})$. After $10 \mathrm{~min}$ in the ice bath, the detergenttreated SPMs were layered onto a cushion of $1.0 \mathrm{M}$ sucrose $(2 \mathrm{ml})$ and centrifuged in the SW 50.1 rotor at $100,000 \times g$ for $90 \mathrm{~min}$. The pellet was the SJ fraction (Nieto-Sampedro et al., 1981a).

Analysis of subcellular fractions. Protein determination (Lowry et al., 1951), electron microscopy of ultrathin sections (Cotman and Taylor, 1972), and SDS-gel electrophoresis in exponential-linear gradients of acrylamide (Kelly and Luttges, 1975; Laemmli, 1970) were carried out as described previously (Nieto-Sampedro et al., 1981a). The apparent molecular weight of SJ proteins was estimated by comparing their electrophoretic mobilities in SUS gels with those of protein standards run in the same gel. These standards were the following (molecular weight in parentheses): microtubule-associated protein (MAP) $1 \quad(\sim 300,000)$, MAP2 $(\sim 270,000)$, myosin $(\sim 200,000), \beta$-galactosidase $(130,000)$, phosphorylase $b$ $(96,000)$, lactoperoxidase $(82,000)$, bovine serum albumin $(68,000), \alpha$-tubulin $(56,000), \beta$-tubulin $(54,000)$, actin $(45,000)$, ovalbumin $(42,000)$, soybean trypsin inhibitor $(21,500)$, and cytochrome $c(11,700)$. The morphological composition of SJs was evaluated quantitatively from electron micrographs as described by Cotman et al. (1974). Concanavalin A (Con A)-binding glycoproteins were identified in SDS-polyacrylamide gels by the method of Rostas et al. (1977); their relative content in SJs was estimated by densitometry of autoradiograms. A similar method was used to detect the binding of antiPSD antibody to gels (Adair et al., 1978) and to estimate the content of antigen PSD-95 (Nieto-Sampedro et al., $1981 b)$. The binding of anti-PSD antiserum R6 in a test tube also was measured as previously described (NietoSampedro et al., 1981b) using ${ }^{125}$ I-labeled protein A as a secondary reagent.

\section{Results}

Subcellular fractionation of brain. The subcellular fractionation of the brain of all of the vertebrates examined followed essentially the same pattern as that described for rat brain (Nieto-Sampedro et al., 1981a). "Light SPMs" sedimented at the interface between 0.8 and $1.0 \mathrm{M}$ sucrose, and "heavy SPMs" banded between the 1.0 and $1.3 \mathrm{~m}$ interface. SJs were obtained by Triton $\mathrm{X}-100$ treatment at $0^{\circ} \mathrm{C}$ of "heavy SPMs." The protein yield in "light SPMs," "heavy SPMs," and SJs was similar to that obtained from the brains of mammals (Table I). In general, the yield of "heavy SPMs" was almost twice as high as that of "light SPMs," although considerable variability was observed in both fractions. The yield of SJs was more constant and, to some extent, inversely proportional to that of the parent SPM fraction (Table I). It seems that the extra protein present in some SPM fractions was predominantly nonjunctional and was solubilized by detergent treatment.

TABLE I

Yield of synaptic plasma membranes and synaptic junctions from the brain of various vertebrate species

The values of the yield reported are an average of the independent preparations indicated in parentheses when more than one was carried out. The standard deviations were within $30 \%$ of the values indicated in the table. The similarity in yields in the four species of Lacertilia suggests that the values reported are a fair index of those to be expected in an average tissue fractionation.

\begin{tabular}{|c|c|c|c|c|c|}
\hline \multirow[b]{2}{*}{ Species } & \multirow{2}{*}{$\begin{array}{c}\text { Amount of } \\
\text { Tissue Pro- } \\
\text { cessed }\end{array}$} & \multicolumn{3}{|c|}{ Yield } & \multirow[b]{2}{*}{ SJ Protein } \\
\hline & & $\begin{array}{l}\text { Light } \\
\text { SPM }\end{array}$ & $\begin{array}{l}\text { Heavy } \\
\text { SPM }\end{array}$ & SJ & \\
\hline & $g m$ & \multicolumn{3}{|c|}{$\begin{array}{c}\text { mg protein/gm wet brain } \\
\text { tissue }\end{array}$} & $\%$ of parent $S P M$ \\
\hline Shark & 15 & 1.6 & 2.3 & 0.25 & 11 \\
\hline Bonito (2) & $2-3$ & 2.0 & 2.7 & 0.70 & 26 \\
\hline Frog (2) & $0.5-3.3$ & 1.8 & 3.0 & 0.60 & 18 \\
\hline Lizard & $0.4-1.2$ & 1.7 & 4.8 & 0.32 & 12 \\
\hline Iguana (2) & $2-3$ & 1.5 & 2.5 & 0.55 & 22 \\
\hline Water monitor & 0.9 & & 2.6 & 0.29 & 11 \\
\hline Golden tegu & 0.9 & & 2.3 & 0.35 & 15 \\
\hline Chicken & $10-15$ & 6.5 & 5.2 & 0.45 & 9 \\
\hline Mouse & $1-4$ & 3.5 & 8.6 & 0.50 & 6 \\
\hline Rat (9) & $20-200$ & 2.4 & 3.0 & 0.46 & 15 \\
\hline Ox (9) & $50-600$ & 1.3 & 2.5 & 0.96 & 38 \\
\hline
\end{tabular}




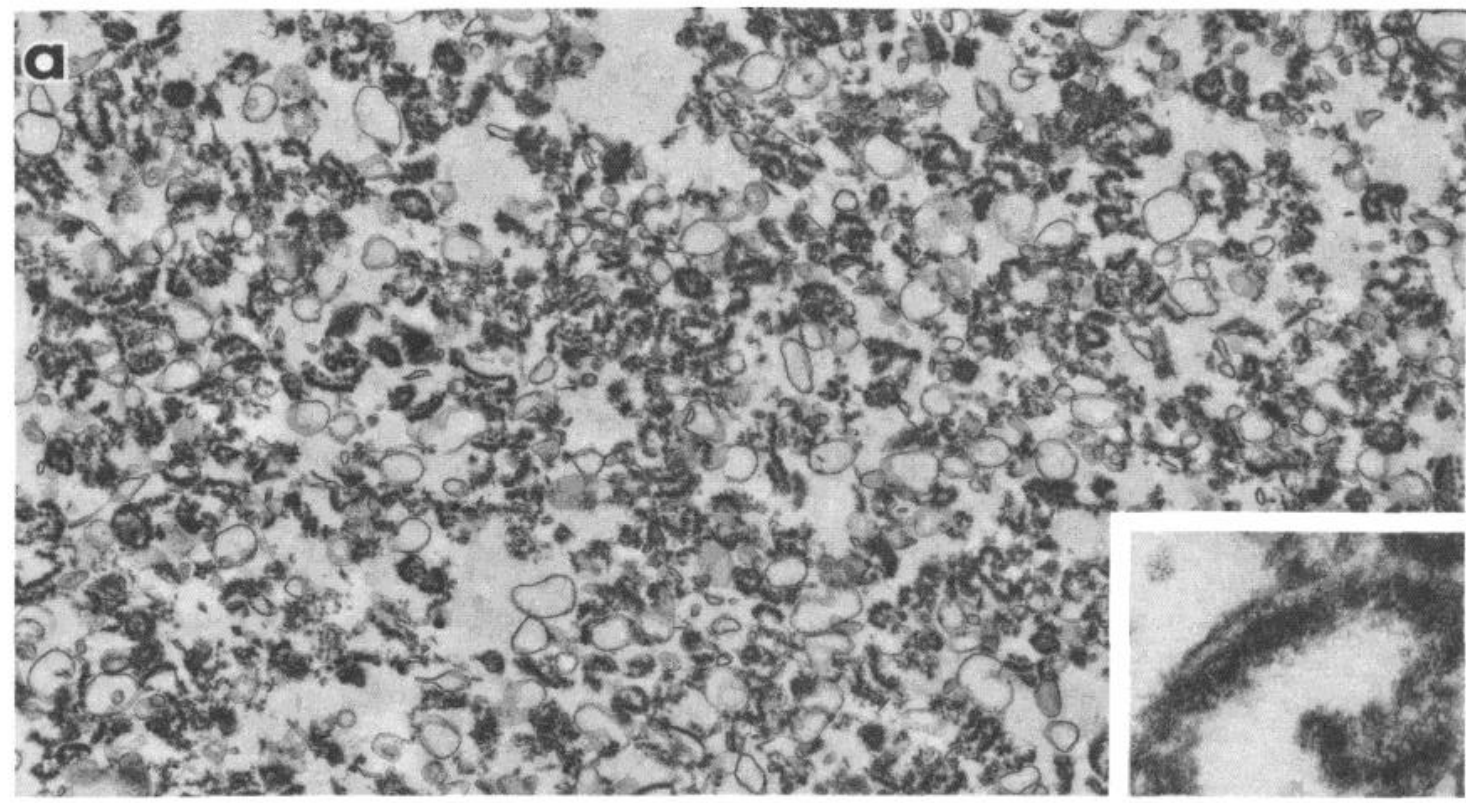

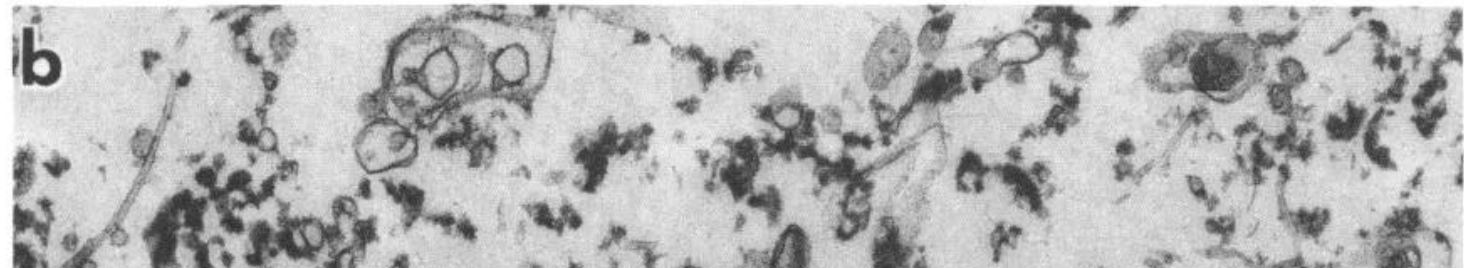
Q. Afof $\therefore=0 x x^{2}$

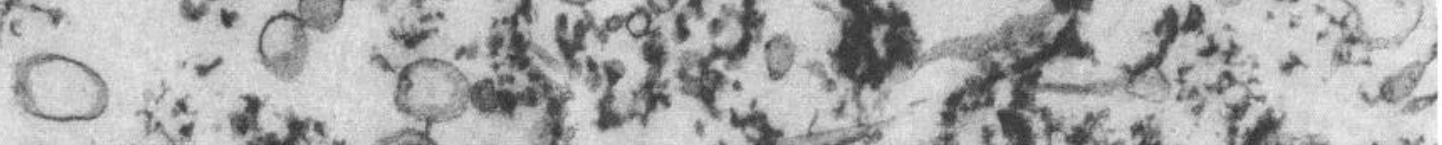

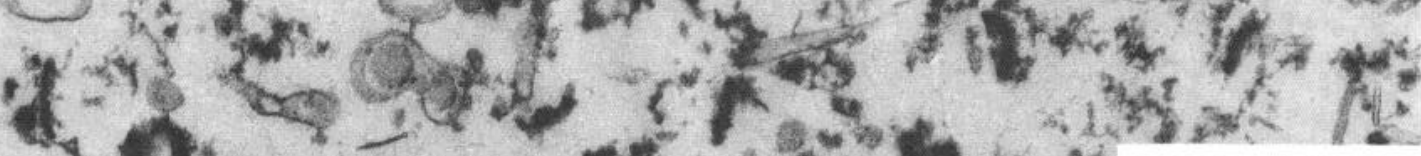

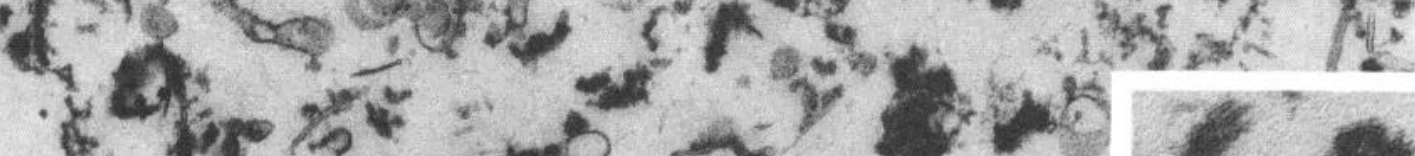

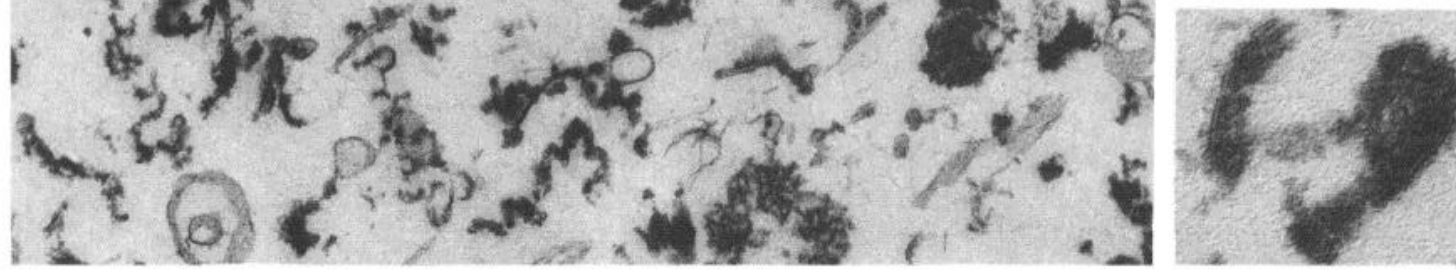

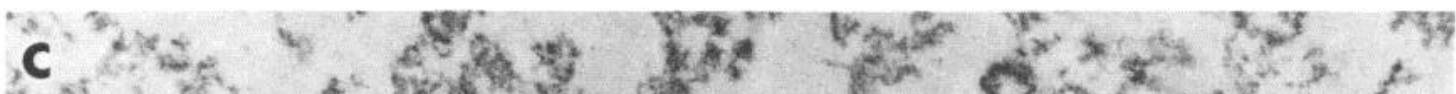

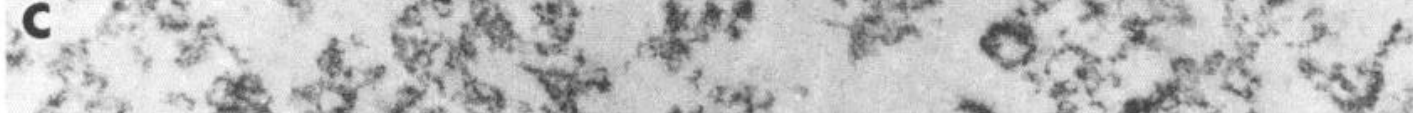

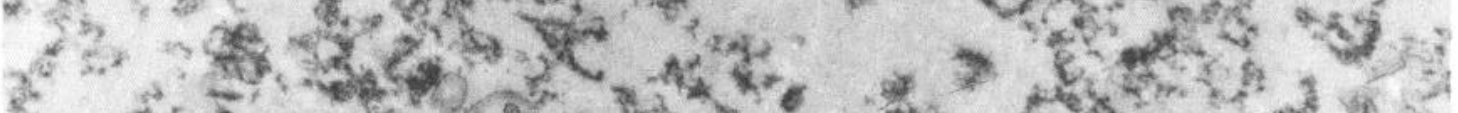

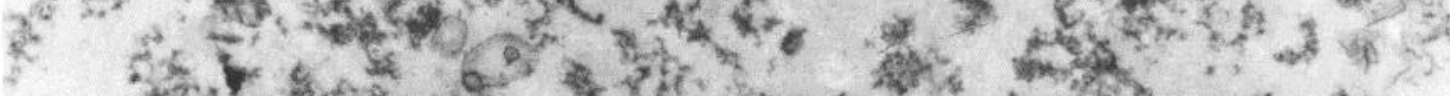

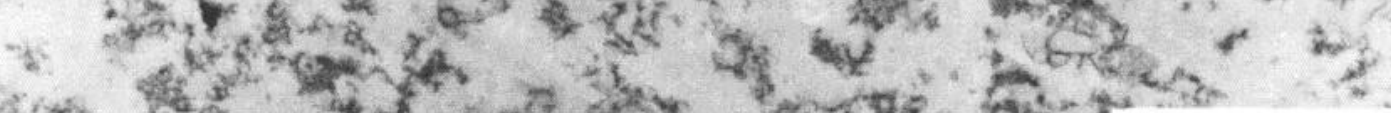

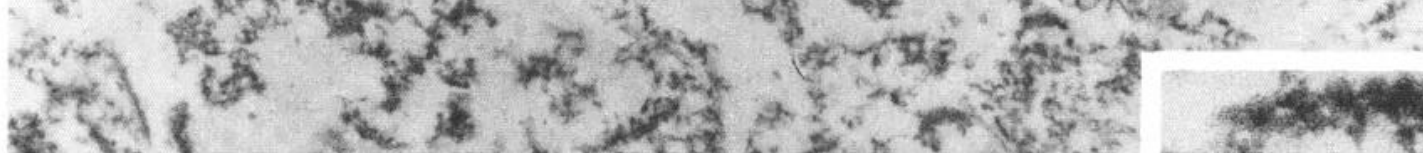

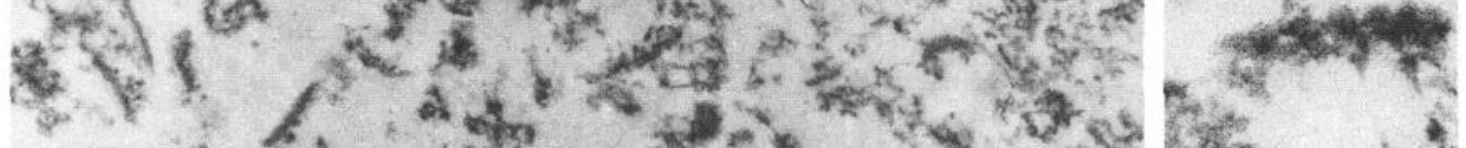

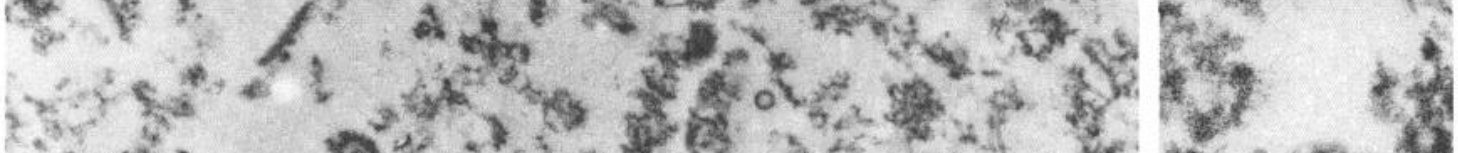
$x^{2} x^{2}(2)+y^{2}$

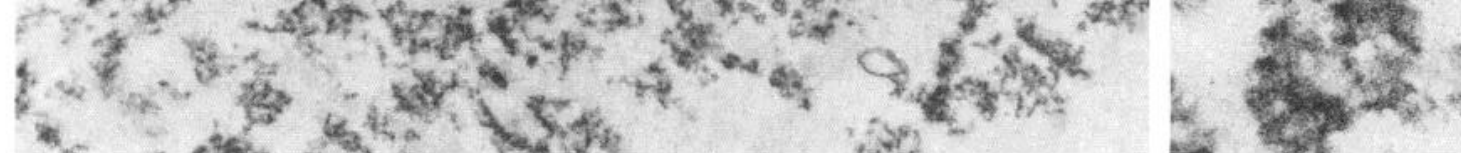


TABLE II

Morphological composition of purified vertebrate synuptic junctions

The profiles observed in the electron micrographs were classified as PSDs when only that structure and no associated membrane was seen and as PSD + PM (PSD plus postsynaptic membrane) if PSDs were overlaid by an associated membrane fragment; SJ structures consisted of characteristic junctions containing both pre- and postsynaptic membrane and a PSD; M represents membrane fragments not associated to PSDs or to each other: "Other" was any other structure, generally microtubules or amorphous material of unknown origin. The area of the different profiles was measured at magnifications of 30,000 to 40,000 with a model MOP-3 integrator (Carl Zeiss, Inc., Thornwood, NY). The maximum deviations in repeated measurements fell within $8 \%$ of the values reported.

\begin{tabular}{|c|c|c|c|c|c|c|c|c|c|c|c|}
\hline \multirow{3}{*}{ Species } & \multirow{3}{*}{$\begin{array}{l}\text { Number of } \\
\text { Profiles } \\
\text { Examined }\end{array}$} & \multicolumn{10}{|c|}{ Characteristics of Structures Observed in Micrographs } \\
\hline & & \multicolumn{5}{|c|}{ Number } & \multicolumn{5}{|c|}{ Area } \\
\hline & & PSI & $\mathrm{PSD}+\mathrm{PM}$ & SJ & $\mathbf{M}$ & Other & PSD & PSD + PM & SJ & $\mathbf{M}$ & Other \\
\hline & & \multicolumn{5}{|c|}{ \% of total } & \multicolumn{5}{|c|}{$\%$ of total } \\
\hline Mouse & 150 & 32 & 30 & 31 & 7 & 0 & 17 & 25 & 53 & 5 & 0 \\
\hline Chicken & 474 & 29 & 40 & 17 & 11 & 3 & 21 & 32 & 30 & 12 & 4 \\
\hline $\begin{array}{l}\text { Water } \\
\text { monitor }\end{array}$ & 375 & 34 & 35 & 18 & 17 & 5 & 23 & 33 & 30 & 10 & 4 \\
\hline Frog & 250 & 26 & 37 & 15 & 11 & 11 & 16 & 30 & 27 & 15 & 11 \\
\hline Bonito & 156 & 37 & 43 & 6 & 10 & 4 & 33 & 47 & 8 & 9 & 3 \\
\hline Shark & 282 & 37 & 40 & 12 & 6 & 5 & 30 & 36 & 25 & 5 & 4 \\
\hline
\end{tabular}

Purity of synaptic junctions. The morphological composition of the different SJ fractions was studied by quantitative electron microscopy. The SJ preparation from mouse was remarkably pure (Fig. $1 a$ ) and was used as standard for comparison in the description of SJs from other species. In general, most of the profiles present in the micrographs could be accounted for by junctional structures (Fig. 1), an observation supported by the quantitative data of Table II. A minimum of 85 to $86 \%$ of the profiles were either PSDs, PSDs with an overlying fragment of postsynaptic membrane, or SJs proper, where both pre- and postsynaptic components could be identified. The latter structures, however, were a minority $(6$ to $31 \%$; Table II), especially in vertebrates lower than mouse on the phylogenetic scale. The majority of the particles consisted of PSDs without recognizable membrane elements (26 to 37\%; Table II) and PSDs with small overlying fragments of postsynaptic membrane (30 to $43 \%$, Table II). The presence of excess postsynaptic components in similar $\mathbf{S J}$ preparations from rat brain had been noted by Churchill et al. (1976). In mammals, SJs proper, that is, profiles containing both pre- and postsynaptic elements, were better preserved; in fish, the preparation consisted predominantly of PSDs with little postsynaptic membrane. We denominate the mixture "SJ fraction," an operational definition that applies to the fraction obtained by the method described by Cotman and Taylor (1972). Other authors (Cohen et al., 1977; Matus and Taff-Jones, 1978) use the term PSDs to describe a similar mixture where PSDs, obtained by more vigorous (Matus and Taff-Jones, 1978) or repeated (Cohen et al., 1977) treatment of SPMs with Triton X100 , predominate. The name is a matter of choice, but we prefer to reserve PSD for the preparation obtained by treatment with sodium $N$-lauroyl sarcosinate (Cotman et al., 1974; Nieto-Sampedro et al., 1981b) because it does not contain any membrane elements and shows a much simpler protein pattern in SDS-gel electrophoresis. Nonjunctional contaminants ("Other" in Table II) were frequently microtubules as well as aggregates of amorphous material.

The shape of the PSDs in thin sections generally took the appearance of C-shaped bars and of roughly circular profiles. Traditionally, these structures have been interpreted as resulting from transverse and frontal sections, respectively, of the disk-like PSD (Peters and Kaisermann-Abramof, 1969; Cohen and Siekevitz, 1978; Matus and Taff-Jones, 1978). The frequency of each of these types of profile (Table III) was similar in all species. An additional type of profile, observed much less frequently, was a perforated circle or doughnut-like structure apparently resulting from the en face view of a perforated PSD (Cohen et al., 1977; Fig. 1c). The average length of the bar-like profiles and the maximum diameter of the circles was in the range 150 to $250 \mathrm{~nm}$, and their thickness was 30 to $40 \mathrm{~nm}$, with rather large standard deviations (Table III). The average size did not show any particular correlation with the position of the animal species in the phylogenetic scale and was comparable to that reported for mammalian PSDs in situ (Peters and KaisermannAbramof, 1969; Cohen and Siekevitz, 1978; Lee et al., 1980). The wide range of dimensions observed can be attributed to the heterogeneous origin of the synaptic complexes, to the fragmentation of the PSD during isolation (Matus and Taff-Jones, 1978) and to the nature of the sectioning process itself.

Protein composition of purified synaptic junctions. The protein composition of SPMs, SJs, and PSDs from mammalian brain has been reported previously (Wang and Mahler, 1976; Blomberg et al., 1977; Cohen et al.,

Figure 1. Ultrastructural appearance of a purified SJ fraction from vertebrate brain. $a$, Mouse brain SJs; complete junctions with both pre- and postsynaptic membranes were most abundant in this preparation. Magnifications: $\times 22,000$; inset, $\times 116,000$. $h$, Frog brain S.Js contained a lower proportion of complete junctions, but many PSDs with associated postsynaptic membrane were observed. Magnifications: $\times 38,000$; inset, $\times 118,000$. $c$, Bonito SJs contained a very low proportion of complete junctions but a large proportion of PSDs alone or associated with small fragments of postsynaptic membrane. Magnification: $\times 32,000$. Inset, PSD viewed en face showing that multiple perforations were more abundant in reptiles and fish. Magnification: $\times 110,000$. 
TABLE III

Morphology of isolated vertebrate synaptic junctions: Shape and dimensions of their postsynaptic densities

Postsynaptic densities were classified as "bar" if they appeared in the section either as a straight or bent bar-like profile. "Circle" PSD profiles had, in fact, an irregular, generally elliptical shape; their most distinctive feature was that their appearance was not that of a bar (i.e., no dimension was clearly predominant). When they presented one or more electron-clear areas or holes, they were classified as "doughnuts." The dimension given for circles and doughnuts is the length of the longer axis. For bars, the length of the bar is given. The PSD thickness was measured in the bar-like profiles. All dimensions were measured with a MOP-3 digital image analyzer (Carl Zeiss, Thornwood, NY).

\begin{tabular}{|c|c|c|c|c|c|c|c|c|}
\hline \multirow{2}{*}{ Species } & \multirow{2}{*}{$\begin{array}{l}\text { Number of } \\
\text { Profiles } \\
\text { Examined }\end{array}$} & \multicolumn{3}{|c|}{ PSD Shape } & \multicolumn{3}{|c|}{ Maximum Diameter \pm SD } & \multirow{2}{*}{$\begin{array}{c}\text { PSD } \\
\text { Thickness } \\
\pm \text { SD }\end{array}$} \\
\hline & & Bar & Circle & Doughnut & Bar & Circle & Doughnut & \\
\hline & & \multicolumn{3}{|c|}{$\%$ of total } & \multicolumn{3}{|c|}{$n m$} & $n m$ \\
\hline Mouse & 150 & 73 & 23 & 4 & $164 \pm 74$ & $145 \pm 50$ & $172 \pm 47$ & $31 \pm 11$ \\
\hline Chicken & 215 & 60 & 35 & 5 & $256 \pm 99$ & $181 \pm 55$ & $198 \pm 30$ & $42 \pm 16$ \\
\hline $\begin{array}{l}\text { Water } \\
\text { monitor }\end{array}$ & 191 & 62 & 26 & 12 & $178 \pm 78$ & $175 \pm 51$ & $165 \pm 39$ & $28 \pm 11$ \\
\hline Frog & 160 & 75 & 20 & 5 & $196 \pm 70$ & $185 \pm 55$ & $217 \pm 46$ & $34 \pm 13$ \\
\hline Bonito & 185 & 72 & 25 & 3 & $167 \pm 74$ & $183 \pm 41$ & $170 \pm 44$ & $40 \pm 18$ \\
\hline Shark & 139 & 64 & 33 & 3 & $235 \pm 68$ & $211 \pm 58$ & $189 \pm 80$ & $40 \pm 19$ \\
\hline
\end{tabular}

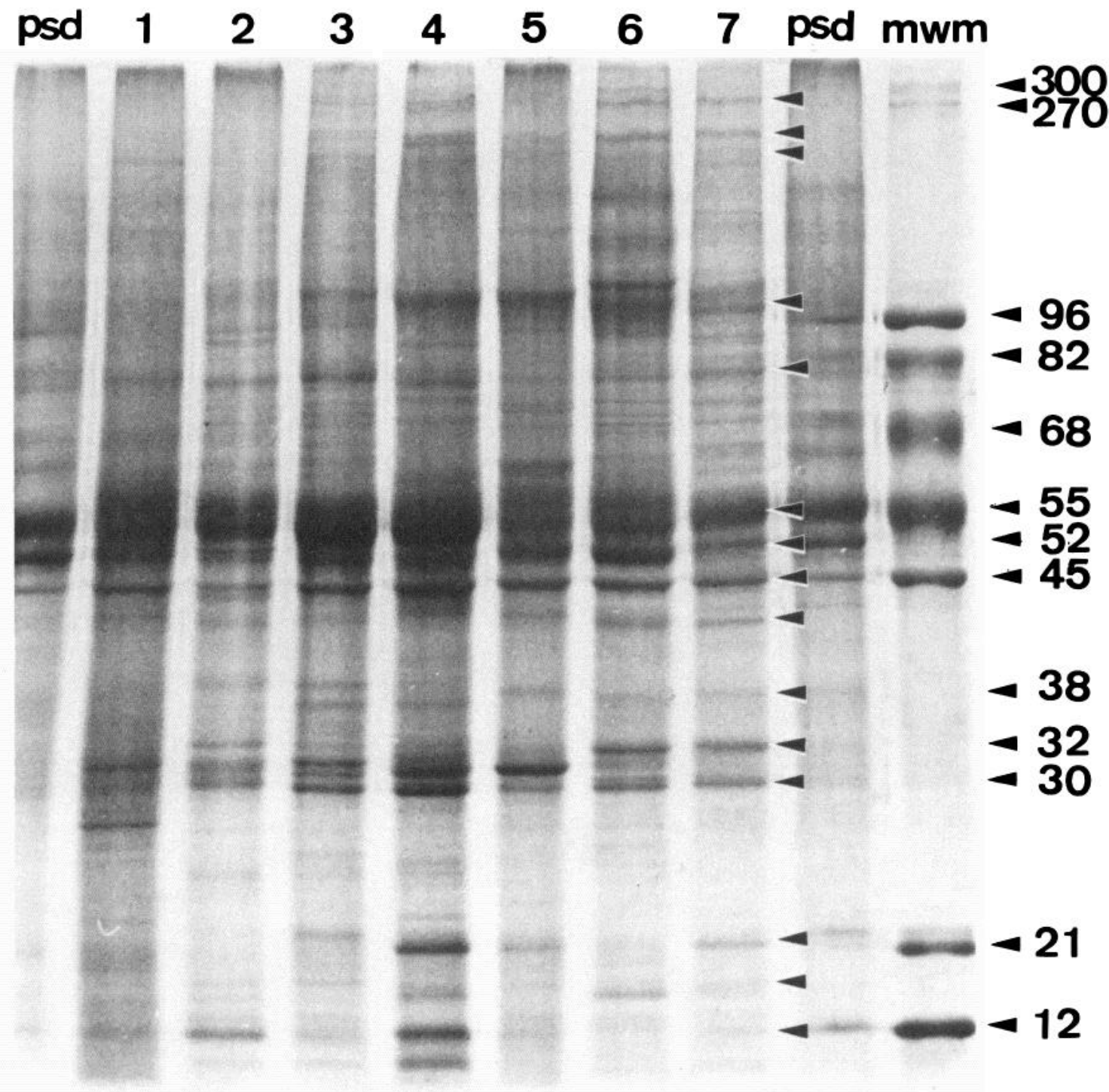

Figure 2. Protein composition of vertebrate brain synaptic junctions. SJ proteins were separated in SDS-polyacrylamide gel slabs (7 to $17.5 \%$ linear-exponential gradient of acrylamide) and stained with Coomassie blue as indicated under "Materials and Methods." mwm, Molecular weight markers of the values $\left(\times 10^{-3}\right)$ indicated at the right of the figure; psd, rat postsynaptic densities (Cotman et al., 1974; Nieto-Sampedro et al., 1981b). Other lanes, SJ from: 1, shark; 2, bonito; 3, common frog; 4, desert iguana; 5 , chicken; 6 , mouse; 7, ox. The SJ samples contained $30 \mu \mathrm{g}$ of protein and psd contained $12 \mu \mathrm{g}$. The arrowheads inside of the gel point to (from top to bottom): SJ-270, SJ-240, SJ-205, SJ-100, SJ-80, SJ-55, SJ-52, SJ-45, SJ-42, SJ-36, SJ-32, SJ-30, SJ20 , SJ-17, and SJ-12, respectively. For possible identity of several of these bands, see Table IV. 
1977; Kelly and Cotman, 1977; Goodrum and Tanaka, 1978; Mahler, 1977; Matus, 1978; Matus and Taff-Jones, 1978; Rostas et al., 1979; Cotman and Kelly, 1980; Matus et al., 1980; Nieto-Sampedro et al., 1981a). The reports from different laboratories are in good agreement, but comparisons could be made easier by adopting a general nomenclature for the different protein components. We will name the different polypeptides by the name of the fraction where they are found, followed by GP if they are glycoproteins, and by the apparent molecular weight of the corresponding band in SDS-polyacrylamide gel electrophoresis divided by 1000 . Thus, a protein band with a molecular weight of 30,000 found in SJ would be SJ-30. The major component of mammalian PSDs, whose molecular weight is about 52,000 (Kelly and Cotman, 1977, 1978; Cohen et al., 1977), would be PSD-52. This system has many shortcomings, such as the lack of total agreement on precise values of apparent molecular weight; however, it is more informative than calling the protein bands $1,2,3, \ldots$ or $\mathbf{a}, \mathbf{b}, \mathbf{c}$, etc. and facilitates the comparison between different species and with the results of other investigators.

The polypeptide pattern of SJs from different vertebrates, as revealed by high resolution SDS-gel electrophoresis (Fig. 2), showed that the major protein bands had identical or similar mobilities in all animal species. Less than 12 bands contributed between 45 and $70 \%$ of the total protein of the SJs. The tentative identity of some of them, based on their electrophoretic mobility and the identity established for similar bands in mammals (Cotman and Kelly, 1980), is given in Table IV. A question mark following the name of the protein indicates that it has been found in the nervous system but not necessarily in SJ. Sometimes, more than one known protein could account for a band of a given molecular weight (SJ-20). The bands that were most abundant had the same mobilities as those of fibrous proteins identified in PSDs, especially tubulins (Walters and Matus, 1975; Wang and Mahler, 1976; Therien and Mushynski, 1976; Feit et al., 1977; Kelly and Cotman, 1978), actin (Cohen et al., 1976; Kelly and Cotman, 1978), and the PSDspecific protein, PSD-52 (Kelly and Cotman, 1977, 1978; Cohen et al., 1977). Other common components, such as SJ-270, SJ-80, SJ-60, SJ-36, SJ-20, SJ-17, and SJ-12, also appeared to be present in mammalian PSDs (Fig. 2), but their identity was not established. Band SJ-17 in particular probably corresponded to calmodulin (Grab et al., 1979,1980 ). Four groups of polypeptides with molecular weights centered on $109,000,100,000,92,000$, and 85,000, respectively, were more abundant in mammals, birds, and reptiles than in lower species (Fig. 2), but SJ-80 and SJ-60 were similar in all species examined. The latter has a molecular weight similar to that of calcineurin, a calcium- and calmodulin-binding protein purified from homogenates of bovine brain (Klee et al., 1979). Interspecies differences in the relative abundance of some bands can result from variations in the content of membrane elements in the SJ preparations from the different vertebrates (Table II). On the other hand, small differences in molecular weight, such as those observed in polypeptides SJ-32 and SJ-30, may arise from species differences between similar proteins or because actually different proteins have similar molecular weights. Polypeptide SJ- 42 had an apparent molecular weight similar to that of a glial filament protein immunochemically identified in rat PSDs (Matus et al., 1980); however, nonmuscle $\beta$-actinin

TABLE IV

Major common proteins of purified synaptic junctions from several vertebrate species

SDS-polyacrylamide gradient gels were cast in slabs 0.5 or $0.8 \mathrm{~mm}$ thick and run as indicated under "Materials and Methods." SJ proteins (20 to $30 \mu \mathrm{g} / \mathrm{sample)}$ were stained with Coomassie blue. Purified chicken gizzard actin and myosin and rat brain microtubules and PSDs were used as standards in addition to commercial proteins.

\begin{tabular}{|c|c|c|c|c|c|c|c|c|c|c|}
\hline \multirow{2}{*}{$\begin{array}{l}\text { Tenuporary } \\
\text { Name }\end{array}$} & \multirow{2}{*}{ Mouse } & \multicolumn{6}{|c|}{ Apparent Molecular Weight in SJ $\left(\times 10^{-3}\right)$} & \multirow[b]{2}{*}{ Shark } & \multirow{2}{*}{$\begin{array}{l}\text { Tentative } \\
\text { Identity }\end{array}$} & \multirow{2}{*}{ Reference } \\
\hline & & Rat & Ox & Chicken & Iguana & Frog & Bonito & & & \\
\hline S.J-270 & 270 & 270 & 275 & n.d." & 285 & n.d. & n.d. & n.d. & MAP2 & Matus et al., 1981 \\
\hline $\begin{array}{l}\text { SJ-240 } \\
\quad \text { (doublet) }\end{array}$ & 240 & 235 & 240 & 230 & 240 & 245 & 245 & 245 & Fodrin & Levine and Willard, 1981 \\
\hline SJ -100 & 101 & 102 & 104 & 108 & 108 & 106 & 108 & 108 & $\alpha$-Actinin? & Schook et al., 1978 \\
\hline SJ-80 & 81 & 81 & 81 & 81 & 81 & 76 & 81 & 81 & & \\
\hline$S J-60$ & 58 & 59 & 60 & 59 & 58 & 56 & 57 & 57 & Calcineurin? & Klee et al., 1979 \\
\hline \multirow[t]{2}{*}{ SJ -55} & 55 & 55 & 55 & 55 & 54 & 53 & 55 & 55 & Tubulins & See text \\
\hline & & & & & & & 51 & & Major PSD & See text \\
\hline PSD-52 & 52 & 52 & 52 & 52 & 51 & 51 & 53 & $52\}$ & protein & \\
\hline \multirow[t]{2}{*}{ SJ -45} & 45 & 45 & 45 & 45 & 44 & 45 & 45 & 45 & Actin & See text \\
\hline & & & & & & & & & Glia filament? & Matus et al., 1980 \\
\hline \multirow[t]{2}{*}{$\mathrm{SJ}-42$} & 41 & 42 & 41 & 42 & 42 & 41 & 42 & 42 & $\beta$-Actinin? & Korn, 1978 \\
\hline & & & & & 37 & 36 & 37 & $37\}$ & & \\
\hline \multirow[t]{2}{*}{ SJ -36} & 36 & 36 & 36 & 36 & 35 & 35 & 36 & $36\}$ & Troponin T? & Puszkin and Kochwa, 1974 \\
\hline & 31 & 31 & & & 31 & & 31 & & & Mahendran and Berl, 1979 \\
\hline SJ -32 & 32 & 32 & 32 & 31 & 32 & 31 & 32 & 31 & & \\
\hline SJ -30 & 29 & 29 & 29 & 29 & 29 & 29 & 30 & 30 & $\begin{array}{l}\text { Tropomyosin? } \\
\text { Troponin I? }\end{array}$ & Blitz and Fine, 1974 \\
\hline $\mathrm{SJ}-20$ & 21 & 21 & 21 & 21 & 21 & 22 & 19 & 21 & $\begin{array}{l}\text { Myosin light } \\
\text { chains? }\end{array}$ & Sce "Discussion" \\
\hline $\mathrm{SJJ}-17$ & 17 & 17 & 17 & 17 & 17 & 17 & 17 & 17 & Calmodulin & Grab et al., 1979 \\
\hline SJ-12 & 13 & 13 & 12 & 12 & 12 & 11 & 12 & 12 & & \\
\hline
\end{tabular}

"n.d., not determined. 
also has a similar molecular weight (Korn, 1978), although its presence in brain has not been reported. The apparent molecular weight of SJ-36 was similar to that of troponin $\mathrm{T}$ from brain synaptosomes (Puszkin and Kochwa, 1974; Mahendran and Berl, 1979), and that of SJ-32 or SJ-30 corresponded to brain tropomyosin (Blitz and Fine, 1974; Puszkin and Kochwa, 1974). Finally, bands SJ-20 and SJ-17 had mobilities similar to those of myosin light chains from brain and adrenal medulla $(23,000,20,000$, and 17,000; Burridge and Bray, 1975; Creutz, 1977; Trifaro, 1978). The identity of the SJ bands, however, was not established.

The relative abundance of the major common components was similar in the various vertebrates species within the variations inherent in multistep subcellular fractionation. However, the known technical difficulties in the precise determination of protein content from densitometric scans of complex patterns of bands prevented a quantitative study at this time.

Concanavalin A-binding glycoproteins of the synaptic junction. The binding of ${ }^{125}$ I-Con A to SDS-gel electropherograms of SJ from mammalian brain presents a comparatively simple pattern, with four major components with apparent molecular weights of about 160,000 , $123,000,115,000$, and 97,000, respectively (Gurd, 1977a, b; Kelly and Cotman, 1977; Rostas et al., 1977, 1979). These glycoproteins, named here S.J.GP-170, SJ.GP-125, SJ.GP-115, and SJ.GP-100, are located in the postsynaptic membrane (Matus et al., 1973; Bittiger and Schnebli, 1974; Cotman and Taylor, 1974) and therefore, if conserved during evolution, should be detectable in our SJ preparations. Scans of the autoradiograms of ${ }^{125} \mathrm{I}$-Con A-treated gels are shown in Figure 3, whereas Table V summarizes the approximate values of the area under the densitometric scans of such autoradiograms. Similar groups of Con A-binding glycoproteins were present in all species examined. However, individual bands did not always have the same molecular weight and relative abundance as in mammals (Table V). For example, a band of molecular weight about 145,000 was a minor component in mammals and amphibia but acquired considerable importance in reptiles and birds (Fig. 3; Table V). On the other hand, SJ.GP-115, the most abundant Con A-binding component in mammals, was in smaller proportion in reptiles and birds. Major differences also were observed in the overall Con A-binding, as well as in the relative binding of Con A to bands SJ.GP-125 and SJ.GP-115 in the lower vertebrate species (Fig. 3). In shark particularly, the four usual groups of glycoproteins were very scarce and the most prominent Con A-binding component had a molecular weight of about 320,000 (Fig. 3).

Conservation of antigen PSD-95. The brain protein called antigen PSD-95 has been shown by us to be located exclusively in the postsynaptic densities of mammalian brain (Nieto-Sampedro et al,, 1981b). The radioimmunochemical determination of PSD-95 in the SJs from the different species was carried out using antibodies to PSD95 from mammal and ${ }^{125} \mathrm{I}$-protein $\mathrm{A}$ as a secondary reagent. Two methods were used, namely binding in a test tube of anti-PSD antibody to native SJs followed by radioactive protein $A$ and binding of antibody and ${ }^{125} \mathrm{I}$ protein A to SDS-polyacrylamide gel electropherograms

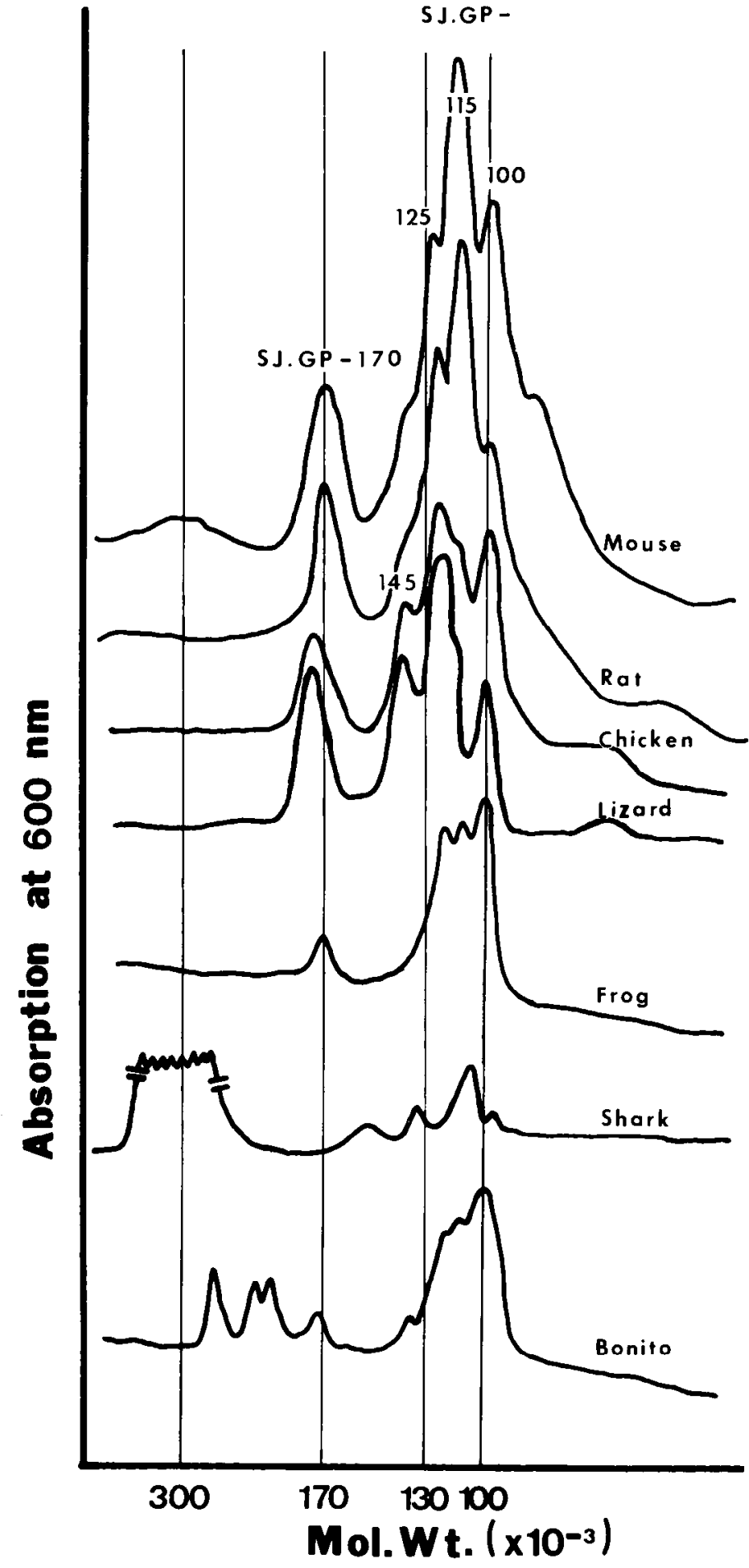

Figure 3. Concanavalin-binding glycoproteins of vertebrate SJ. SDS-gel electropherograms as in Figure 2 were fixed, treated with ${ }^{125} \mathrm{I}$-Con $\mathrm{A}$, dried, and autoradiographed. The figure shows freehand tracings of the densitometric scans of such autoradiograms averaging three to five independent binding experiments. On the abscissa, the molecular weight is given. The most abundant glycocomponents of shark SJ $(310,000$ to $330,000)$ were absent in the other vertebrates.

of denatured SJs. Whereas the test tube assay allows the measurement of total antibody binding, the SDS-gel assay also permits the semiquantitative determination of binding to individual antigens. The results of both meth- 
TABLE V

Concanavalin A-binding glycoproteins of purified synaptic junctions from various vertebrate species

The binding of ${ }^{125} \mathrm{I}$-concanavalin A to SDS-polyacrylamide gel electropherograms of purified SJs was carried out as described by Rostas et al. (1977). The major lectin-binding glycoproteins are named SJ.GP-170 to SJ.GP-100, according to their approximate molecular weight. Their molecular weight values $\left(M_{\mathrm{r}}\right)$ were calculated from their mobility in SDS gels. Bands SJ.GP-170, SJ.GP-125, SJ.GP-115, and SJ.GP-100 have been denominated previously Con A I, Con A II, Con A III, and Con A IV, respectively (Kelly and Cotman, 1977; Rostas et al., 1979). Their respective molecular weight in mammals and chicken were reported as: 160,000 to $165,000,123,000,108,000$ to 118,000 , and 95,000 to 100,000 (Rostas et al., 1979). Total binding of the lectin as well as binding to individual bands was estimated in at least three independent experiments for each species by measuring the area of densitometric tracings of the autoradiograms with a MOP-3 electronic integrator (Zeiss, Inc., Thornwood, NY). Total binding is expressed relative to total binding to mouse SJ. Binding to individual bands is relative to binding to band SJ.GP-170 of the same species, with maximum deviations from the average ratios reported in the table smaller than $20 \%$. Similar values of the ratios were obtained for rat SJ by cutting out the gel bands after treatment with ${ }^{125} \mathrm{I}$-Con $\mathrm{A}$ and counting their radioactive content in a Gamma counter.

\begin{tabular}{|c|c|c|c|c|c|c|c|c|c|c|c|}
\hline \multirow{2}{*}{$\begin{array}{l}\text { Animal } \\
\text { Species }\end{array}$} & \multirow{2}{*}{$\begin{array}{c}\text { Total } \\
\text { Con A } \\
\text { Binding } \\
\text { (Mouse }=100 \%)\end{array}$} & \multicolumn{2}{|c|}{$\begin{array}{l}\text { SJ.GP-170 } \\
\text { (Con A I) }\end{array}$} & \multicolumn{2}{|c|}{ SJ.GP-145 } & \multicolumn{2}{|c|}{$\begin{array}{l}\text { SJ.GP-125 } \\
\text { (Con A II) }\end{array}$} & \multicolumn{2}{|c|}{$\begin{array}{l}\text { SJ.GP-115 } \\
\text { (Con A III) }\end{array}$} & \multicolumn{2}{|c|}{$\begin{array}{l}\text { SJ.GP-100 } \\
\text { (Con A IV) }\end{array}$} \\
\hline & & $\begin{array}{l}\text { Relative } \\
\text { Binding }\end{array}$ & $\begin{array}{c}M_{\mathrm{r}} \\
\left(\times 10^{-3}\right)\end{array}$ & $\begin{array}{l}\text { Relative } \\
\text { Binding }\end{array}$ & $\begin{array}{c}M_{s} \\
\left(\times 10^{-11}\right)\end{array}$ & $\begin{array}{l}\text { Relative } \\
\text { Content }\end{array}$ & $\begin{array}{c}M_{v} \\
\left(\times 10^{-3}\right)\end{array}$ & $\begin{array}{l}\text { Relative } \\
\text { Content }\end{array}$ & $\begin{array}{c}M_{\mathrm{r}} \\
\left(\times 10^{-3}\right)\end{array}$ & $\begin{array}{l}\text { Relative } \\
\text { Content }\end{array}$ & $\begin{array}{c}M_{i} \\
\left(\times 10^{-11}\right)\end{array}$ \\
\hline Mouse & 100 & 1.0 & $166-177$ & 0.6 & $135-140$ & 1.0 & $125-128$ & 2.1 & $116-119$ & 1.7 & $98-107$ \\
\hline Rat & $76-112$ & 1.0 & $166-177$ & 0.6 & $135-140$ & 1.1 & $123-128$ & 1.5 & $118-119$ & 1.1 & $98-107$ \\
\hline Chicken & $40-57$ & 1.0 & $175-182$ & 0.7 & $138-145$ & 1.6 & $123-128$ & 0.8 & $108-118$ & 1.3 & $97-107$ \\
\hline $\begin{array}{c}\text { Golden } \\
\text { tegu }\end{array}$ & 38 & 1.0 & $180-190$ & 1.3 & $146-150$ & 1.7 & $130-138$ & 1.1 & $113-118$ & 1.2 & $100-104$ \\
\hline $\begin{array}{l}\text { Water } \\
\text { monitor }\end{array}$ & 46 & 1.0 & $180-190$ & 1.4 & $145-155$ & 1.9 & $130-135$ & 1.1 & $118-120$ & 1.1 & $97-102$ \\
\hline Frog & 25 & 1.0 & 170 & 0.8 & 145 & 3.0 & 122 & 2.5 & 115 & 4.3 & 107 \\
\hline Bonito & 21 & 1.0 & 175 & 0.7 & 140 & 3.0 & 118 & 2.6 & 113 & 6.6 & 102 \\
\hline Shark & $8^{\prime \prime}$ & 1.0 & 155 & 1.2 & 138 & & & 2.2 & 107 & 0.5 & 97 \\
\hline
\end{tabular}

${ }^{a}$ Calculated excluding the $M_{\mathrm{r}}=320,000$ band. If this component was included, the total binding rose to $30 \%$.

ods were in good agreement with each other for mammalian brain fractions (Nieto-Sampedro et al., 1981b). In the brain of rodents, the antiserum used here reacted with tubulins, antigen PSD-95, and to a very small extent, with a band called antigen PSD-82 (Nieto-Sampedro et al., 1981b) and a similar distribution of serum binding was observed in the lower vertebrates with the exception of shark (Fig. 4). However, a noticeable difference between mammals and lower vertebrates was that the total amount of antibody binding to PSD-95 (Table VI) decreased continuously when moving down the phylogenetic scale from rodent to shark. Also, small but definite changes were observed in the molecular weight of PSD95 in species other than mammals (Fig. 4; Table VI). Apparently, the protein molecule carrying the PSD-95 antigenic determinants had undergone some modifications in sequence and/or conformation during evolution. In shark, in addition to PSD-95, two additional bands with molecular weights of 140,000 and 155,000 also were recognized by the antiserum.

In contrast to PSD-95, binding to tubulins was similar in all species (i.e., 10 to $20 \%$ of the total binding to mouse SJ), correlating with a similar content of tubulins in the SJs observed by densitometric scanning of gels stained with Coomassie blue (Fig. 2).

Subcellular distribution of PSD.95. The antigen was present in the synaptic junctions of all of the vertebrate species examined and to test whether its localization was restricted to the PSDs as in mammals, we measured the anti-PSD antibody binding to different subcellular fractions, both in the test tube and in SDS-gel electrophoresis. The maximum amount of antibody binding per unit weight of protein to different brain subfractions was compared to the binding to brain homogenate from the same species (Table VII). As expected for a PSD localization, the highest binding was to SJs or PSDs in all cases. The enrichment in SJs with respect to heavy SPM was about 5 -fold, whereas that of other junctional molecules, such as kainate receptors, was up to 10 -fold (Foster et al., 1981).

The comparatively low enrichment of PSD-95 in SJ compared to SPM suggested that the antigen may be partly solubilized from SPM by Triton X-100 during the preparation of junctions. To test this hypothesis, we examined the binding of anti-PSD antibodies to the Triton X-100-soluble fraction of ox and bonito SPMs in SDS gels. The binding obtained was 46 and $55 \%$, respectively, of the total binding to "heavy SPM." A similar solubilization took place during the preparation of PSDs by treatment of SPMs with the carboxylic detergent sodium $N$-lauroyl sarcosinate: $67 \%$ of the antigen in rat SPMs and $63 \%$ in bovine SPMs were detergent soluble. The amount of PSD-95 solubilized by detergent during the preparation of SJs or PSDs also was estimated from the difference between the total content of the antigen in SPMs and its recovery in SJs or PSDs. The calculated values showed that 60 to $80 \%$ of PSD-95 was solubilized by Triton X-100 and 80 to $90 \%$ by sarcosinate. The solubility in detergent was similar in all species. The maximum enrichment of the antigen in SJ and PSD if none were solubilized by detergent (25- to 95 -fold in SJS and 80 - to 120 -fold in PSDs) compared well with the maximum enrichment theoretically possible for a molecule located exclusively in the PSD (about 100-fold in SJs and about 200-fold in PSDs).

The mitochondrial fraction of all species showed a high content of PSD-95 compared to microsomes or myelin. If the antigen were located exclusively in the PSD, then its presence in mitochondrial fractions could be due only to contamination of these organelles by synaptic junctional complexes or adhering PSD material. Contamination of mitochondria by SPM has been reported previ- 


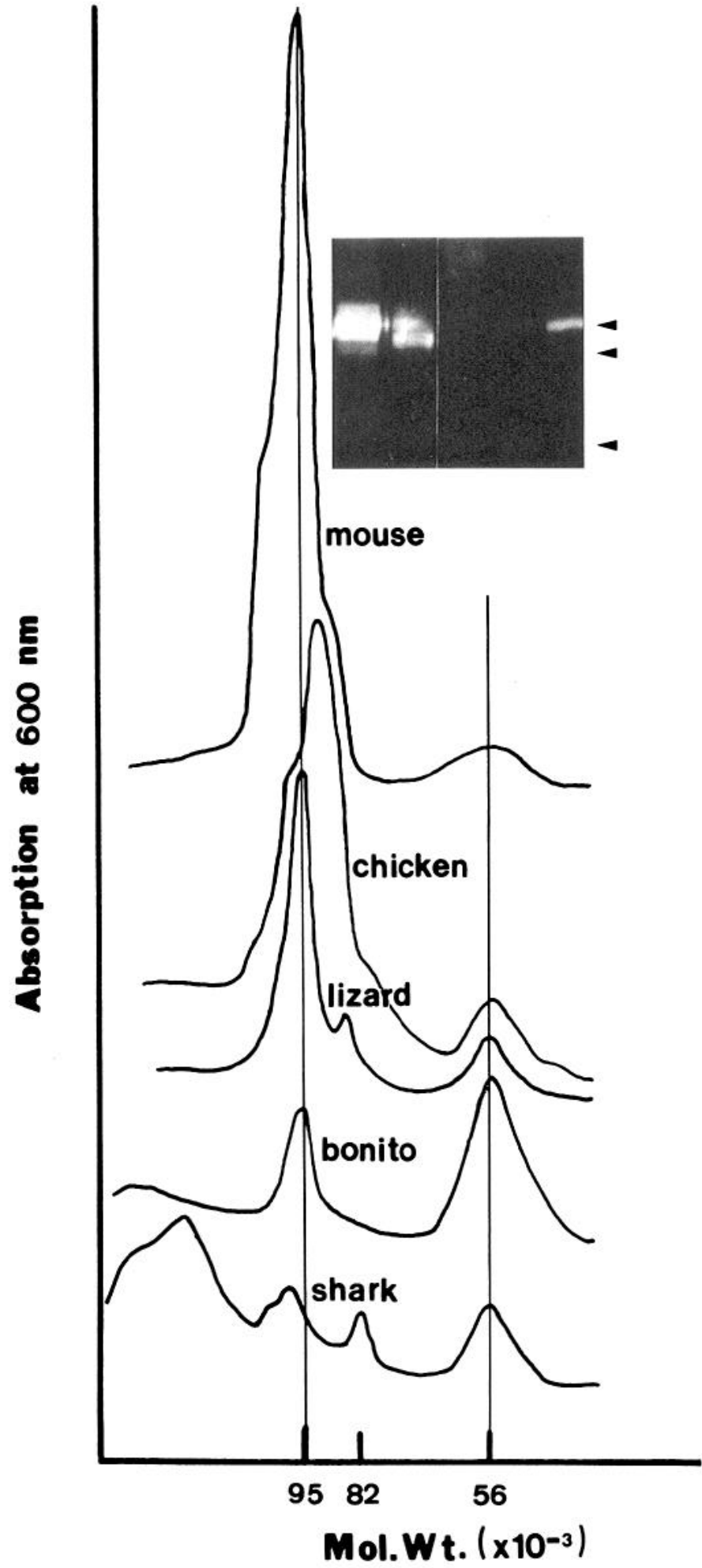

Figure 4. Antigen PSD-95 in vertebrate synaptic junctions. SDS-polyacrylamide gels were fixed, washed, treated sequentially with anti-bovine PSD antiserum (Nieto-Sampedro et al., $1981 \mathrm{~b})$ and ${ }^{125}$ I-protein A, dried, and autoradiographed. The figure shows densitometric scans of such autoradiograms and a contact print of one of the autoradiograms from which the scans were generated. On the abscissa, the molecular weight is given. The arrowheads point to antigens PSD-95, PSD-82, and tubulins. Lane identity, from left to right, SJs from: mouse, chicken, shark, bonito, and fence lizard. ously (Cohen et al., 1977), but it was estimated not to exceed about $20 \%$ of the total mitochondrial protein (Nieto-Sampedro et al., 1981). However, mitochondria from shark, bonito, and one of the reptile preparations contained 29 to $57 \%$ of the antigen binding present in SJs, which would indicate either a nonspecific distribution of PSD-95 or a contamination by junctional membranes greater than expected. The extent of contamination of mitochondria by SPMs could be assesed independently because mitochondria do not contain high molecular weight proteins or glycoproteins. The Coomassie blue pattern of staining of SDS gels of lizard and shark mitochondrial fractions as well as autoradiograms of their binding to ${ }^{125} \mathrm{I}$-Con $\mathrm{A}$, is compared in Figure 5 to the corresponding patterns for heavy SPMs from the same species. The mitochondrial fractions are seen to be quite heavily contaminated by SPMs. The extent of contamination, estimated independently by densitometry of the autoradiograms and of the doublet SJ-240 in the Coomassie blue pattern (Fig. 5), was similar to that calculated from PSD-95 binding. Thus, in shark, densitometry of SJ-240 indicated $37 \%$ contamination of mitochondria by SPMs; Con A binding showed $58 \%$, and binding of antiPSD antibody showed $57 \%$. In the preparation from fence lizard, the corresponding values were $53 \%$ (SJ-240), $42 \%$ (Con A), and $72 \%$ (antibody). Similar measures in four different rat preparations gave $20 \pm 10 \%, 23 \pm 8 \%$, and 32 $\pm 5 \%$, respectively. The slightly higher contamination

TABLE VI

Relative content of antigen PSD-95 in synaptic junctions isolated from various vertebrate species

Maximum binding of anti-PSD antibodies to S.J fractions (test tube assay) and binding to PSD-95 (binding to SDS-gel electropherograms) were determined with the help of ${ }^{12 i} \mathrm{I}$-protein $\mathrm{A}$ as described by NietoSampedro et al. (1981b) using $20 \mu \mathrm{g}$ of SJ protein. The content of PSD95 per $20 \mu \mathrm{g}$ of protein was estimated by measuring the area of densitometric tracings of gel autoradiograms. The values of these areas are expressed relative to those for mouse S.J, averaging the results of three to eight determinations (maximum deviations, $\pm 12 \%$ for total binding and $\pm 30 \%$ for binding to PSD-95). The specific radioactivity of the ${ }^{125} \mathrm{I}$-protein A preparation used was $1.8 \times 10^{7} \mathrm{cpm} / \mu \mathrm{g}$ of protein (efficiency of counting, 70\%). Binding of antibody to mouse SJ in the test tube assay led to binding of $2.3 \pm 0.3$ pmol of ${ }^{125} \mathrm{I}$-protein $\mathrm{A} / \mathrm{mg}$ of SJ protein. Binding to SJs in gels was 40 to $70 \%$ of that observed in the test tube for the same amount of SJ protein. For mouse SJ, it ranged from 7,000 to $20,000 \mathrm{cpm} / 20 \mu \mathrm{g}$ of SJ protein. In the gel assay, it was determined that more than $85 \%$ of the total antibody binding was to antigen PSD-95. Notable exceptions were ox SJs, where binding to PSD-95 represented only $60 \%$ of the total (Nieto-Sampedro et al., 1981b), and shark, where it accounted for only $25 \%$ of the binding. In shark, $67 \%$ of the reaction with antibody took place at two broad bands with molecular weights of 140,000 and 155,000 , respectively.

\begin{tabular}{lccc}
\hline $\begin{array}{c}\text { Animal } \\
\text { Species }\end{array}$ & $\begin{array}{c}\text { Total Anti- } \\
\text { PSD Binding }\end{array}$ & $\begin{array}{c}\text { Binding to } \\
\text { PSD-95 }\end{array}$ & $\begin{array}{c}M_{r} \text { of Major } \\
\text { Antigen }\end{array}$ \\
\hline \multicolumn{4}{c}{ \% of mouse $S J$} \\
Mouse & 100 & 100 & \\
Rat & 104 & 82 & 95,000 \\
Ox & 73 & 48 & 95,000 \\
Chicken & 75 & 65 & 95,000 \\
Lizard & 40 & 35 & 93,000 \\
Frog & & 26 & 96,000 \\
Bonito & 65 & 25 & 102,000 \\
Shark & 43 & 12 & 95,000 \\
& & & 97,000 \\
\hline
\end{tabular}


TABLE VII

Recovery of antigen PSD.95 in subcellular fractions from vertebrate brain

The binding of tubulin-absorbed antiserum to particulate fractions was measured as indicated in Table VI. The binding to microsomes ( $\mathrm{P}$ : fraction), "light SPMs," myelin, and mitochondria was carried out using $100 \mu \mathrm{g}$ of protein; binding to "heavy SPMs" and to SJs was performed on 50 and $20 \mu \mathrm{g}$, respectively. The concentrations of tubulin-adsorbed serum (1/500 dilution) and ${ }^{125} \mathrm{I}-\mathrm{proteein} \mathrm{A}\left(1 \mu \mathrm{g} / \mathrm{ml}, 2.4 \times 10^{7} \mathrm{dpm} / \mu \mathrm{g}\right) \mathrm{used}$ were saturating. The binding to cytoplasmic soluble components ( $\mathrm{S}_{3}$ fraction) was determined on SDS-gel electropherograms (Adair et al., 1978; Nieto-Sampedro et al., 1981b). The results are the average of three to eight independent determinations where maximum deviations were lower than $20 \%$ of the values reported.

\begin{tabular}{|c|c|c|c|c|c|c|c|c|c|}
\hline \multirow{2}{*}{$\begin{array}{l}\text { Animal } \\
\text { Species }\end{array}$} & \multicolumn{9}{|c|}{$\begin{array}{l}\text { Binding of Anti-PSD Antibody to Brain Subcellular Fractions } \\
\text { (Binding to Brain Homogenate }=1.00 \text { ) }\end{array}$} \\
\hline & $\begin{array}{c}\text { Nuclear } \\
\text { Pellet } \\
\left(\mathrm{P}_{1}\right)\end{array}$ & $\begin{array}{l}\text { Cytosol } \\
\left(\mathrm{S}_{i 1}\right)\end{array}$ & $\begin{array}{l}\text { Microsomes } \\
\left(\mathrm{P}_{\mathrm{s}}\right)\end{array}$ & Myelin & Mitochondria & $\begin{array}{l}\text { Light } \\
\text { SPM }\end{array}$ & $\begin{array}{l}\text { Heavy } \\
\text { SPM }\end{array}$ & SJ & PSD \\
\hline Mouse & 0.83 & 0.0 & 0.86 & 0.85 & & 2.46 & 3.70 & 7.20 & \\
\hline Rat & 1.02 & 0.0 & 1.10 & 0.91 & 1.61 & 2.18 & 5.03 & 10.55 & 13.1 \\
\hline $\mathrm{Ox}$ & 1.13 & 0.0 & 0.41 & 0.70 & 3.58 & 2.76 & 6.50 & 9.2 & 15.8 \\
\hline Chicken & 0.83 & 0.0 & 0.21 & 1.21 & & 2.22 & 2.96 & 7.82 & \\
\hline Lizard & 0.60 & 0.0 & 0.94 & 2.05 & 2.95 & 2.39 & 4.12 & 9.7 & \\
\hline Frog & 0.98 & 0.0 & 1.29 & 2.24 & & 2.32 & 4.00 & 15.0 & \\
\hline Bonito & 0.71 & 0.15 & 0.64 & 1.97 & 1.58 & 2.42 & 5.53 & 7.5 & \\
\hline Shark & 0.60 & 0.20 & 0.60 & 2.81 & 5.4 & 2.40 & 9.40 & 10.0 & \\
\hline
\end{tabular}

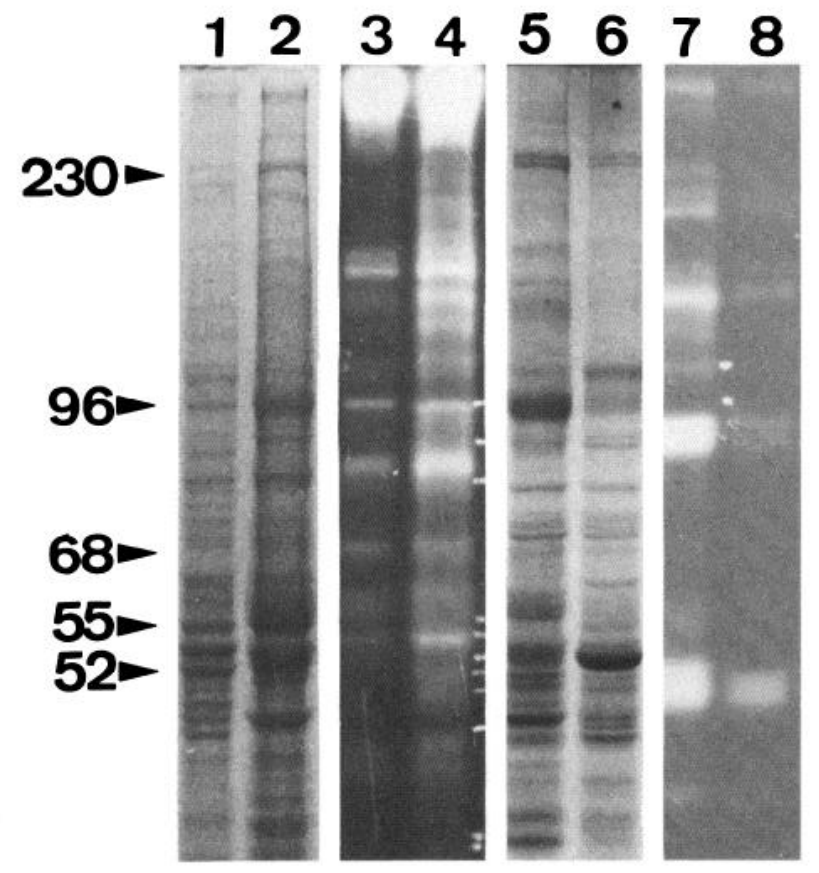

Figure 5. Contamination of mitochondrial fractions by synaptic plasma membranes. Identity of the lanes: Coomassie blue staining pattern of SDS-polyacrylamide gels of: 1 , shark mitochondria; 2 , shark SPM; 5 , lizard SPM; 6 , lizard mitochondria. Autoradiograms of the same gels after treatment with ${ }^{125}$ I-Con A are as follows: 3, shark mitochondria; 4, shark SPM; 7, lizard SPM; 8, lizard mitochondria. Con A-binding glycoproteins and protein SJ-230 were used in the densitometric estimation of contamination of mitochondria by SPM (Nieto-Sampedro et al., 1981a). On the ordinate, the molecular weight $\left(\times 10^{-3}\right)$ is given.

predicted by anti-PSD-95 binding data probably indicates that some of the PSD material in the mitochondrial pellet was not associated with membranes. Unidentified amorphous material was, in fact, observed in immunohistochemical staining of rat SJs by anti-PSD antiserum (Nieto-Sampedro et al., 1981b) and binding to similar material also has been observed in mitochondrial fractions (M. Nieto-Sampedro, S. F. Hoff, and C. W. Cotman, unpublished observations). The agreement between the different methods of determination of mitochondrial contamination suggests that the antibody binding observed in fractions of nonsynaptic origin, such as microsomes and myelin (Table VII), most likely reflects the extent of contamination of these fractions by junctional SPMs.

Identity of PSD-95. None of a number of known membrane or membrane-attached proteins with a molecular weight of 95,000 cross-reacted with antibodies to PSD95. This includes the Con A-binding glycoprotein SJ.GP$100, \alpha$-actinin, the catalytic subunit of $\left(\mathrm{Na}^{+}, \mathrm{K}^{+}\right)$-ATPase, or the polypeptides with a molecular weight of 95,000 from the membranes of thymocytes (Brown et al., 1981) and intestinal brush borders (Craig and Lancashire, 1980). Also, we found no cross-reactivity with total particulate material from mammalian liver, kidney, heart, erythrocytes, macrophages, thymocytes, or intestinal epithelium. PSD-95 seems unique to the postsynaptic density, but its identity and function remain to be established.

\section{Discussion}

Synaptic junction morphology. Our SJ preparations were dominated in appearance and protein composition by prominent PSDs, whose shape was that of flattened ellipsoids, with or without holes in the middle. Doughnutlike profiles were observed initially in the largest PSDs in intact tissue of the rat cerebral cortex (Peters and Kaisermann-Abramof, 1969), and the observation was later confirmed both in isolated PSDs (Cohen et al., 1977) and intact cerebral cortex of the dog (Cohen and Siekevitz, 1978). The observation that perforated PSDs are a feature common to all vertebrate species suggests that PSD perforations must be either essential to synapse function or a necessary intermediate in the renewal of postsynaptic densities.

Conservation of SJ protein and glycoprotein composition. The bulk of the protein of the SJ preparations 
from all of the animal species examined is contributed by comparatively few bands. Out of the 12 or so most abundant protein bands common to all of the $\mathrm{SJ}$, at least 5 have the same mobility as that of known fibrous proteins, i.e., proteins able to associate to form insoluble filaments. Some of them, such as the tubulins, actin, and myosin, have been identified in the synaptic junctions of mammals (Walters and Matus, 1975; Blomberg et al., 1977; Therien and Mushynski, 1976; Feit et al., 1977; Wang and Mahler, 1976; Cohen et al., 1976, 1977; Matus and Taff-Jones, 1978; Cotman and Kelly, 1980; Beach et al., 1981) and their identity in other species is likely to be the same. The major component unique to the mammalian PSD, a protein with a molecular weight of 52,000 (PSD-52), is also present in a high proportion and with the same molecular weight in all vertebrates (Fig. 2). The identity of the remaining bands has not been established in any instance. Band SJ-270 has the same mobility and band multiplicity as MAP2, one of the groups of proteins associated with microtubules both in the cytoplasm and in nonjunctional plasma membranes (Wang and Mahler, 1976; Mahler, 1977). Its presence in mammalian junctions has been reported recently (Matus 1981; Matus et al., 1981). Band SJ-240, usually found as a doublet, is distributed homogeneously in junctional and extrajunctional membranes (Nieto-Sampedro et al., 1981a). This group of proteins has been denominated previously bands 3 and 4 by Goodrum and Tanaka (1978) and band $a$ by us (Nieto-Sampedro et al., 1981a). Its apparent molecular weight has been reported variously as 185,000 (Cohen et al., 1977; Goodrum and Tanaka, 1978) and 280,000 (Matus et al., 1980), but the most frequent value is close to 240,000 (Wang and Mahler, 1976; Kelly and Cotman, 1978; Nieto-Sampedro et al., 1981a) as reported here. This doublet is most likely identical to polypeptides 26 and 27 of Willard et al. (1974) that are transported in retinogeniculate axons at a rate of 34 to $58 \mathrm{~mm} /$ day. Its purification has been reported recently by Levine and Willard (1981) who find that it is constiluted of two components with molecular weights of 250,000 and 230,000 , respectively. Mixtures of fodrin, as the doublet is called by the above authors, and actin associate in vitro (Willard, 1977; Levine and Willard, 1981). These components are sensitive to a specific $\mathrm{Ca}^{2+}$-activated protease and their limited digestion has been proposed to mediate the unmasking of new junctional glutamate receptors (Baudry et al., 1981).

There are several fibrous proteins, some of them reported in brain subfractions, that have the required electrophoretic mobility to account for bands of molecular weight like those of SJ-100, SJ-42, SJ-36, SJ-32, SJ-30, SJ-20, and the bands in the range of 15,000 to 17,000 . Thus, for example, $\alpha$-actinin (Schook et al., 1978), $\beta$ actinin (Korn, 1978), troponins T, I, and C (Puszkin and Kochwa, 1974; Mahendran and Berl, 1979), low molecular weight glial filament components (Matus et al., 1980), myosin light chains (Burridge and Bray, 1975; Creutz, 1977; Trifaró, 1978), calmodulin (Grab et al., 1979, 1980; Wood et al., 1980), and profilin (Korn, 1978) meet this requirement. None of these proteins, except calmodulin (Grab et al., 1980) and glial filaments (Matus et al., 1980), has been identified in $\mathrm{SJ}$ fractions, and the latter is presumably a contaminant. Therefore, the tentative identities listed in Table IV with a question mark are essentially a guess. Also, there is no evidence that those bands in SJs from different species that have the same mobility in SDS gels must have the same identity. On the other hand, highly conserved electrophoretic mobility points out protein components whose identity may be conserved during evolution and, therefore, deserve further examination as they may be essential to general synapse physiology.

The apparent conservation of SJ components extends to Con A-binding glycoproteins and antigen PSD-95. Similar groups of Con A-binding glycoproteins with comparable electrophoretic mobilities in SDS gels are found in all vertebrate SJs. The implication is that Con Abinding components are important in some essential aspect of synapse structure and/or function. In mammals, these components are located in the postsynaptic membrane, with their glycan chains extending to the synaptic cleft (Matus et al., 1973; Bittiger and Schnebli, 1974; Cotman and Taylor, 1974; Kelly et al., 1976). Component SJ.GP-170 probably is distributed homogeneously in both extrajunctional and junctional regions of the plasma membrane. However, components SJ.GP-100, SJ.GP-115, SJ.GP-125, and SJ.GP-145 seem to be enriched selectively in the junctional membrane. Their role remains unknown, but it is tempting to postulate that at least some of these glycoproteins will be involved in the maintenance of junctional adhesion. Together with conservation, considerable divergence is also observed. The diminution in the total amount of Con A binding in lower species as they become more distant from mammals may be due to an absolute decrease in the content of these glycoproteins or perhaps to the presence of a lower proportion of the sugar residues responsible for Con A binding, namely mannose and glucose. In shark, the major Con A-binding components (also present in microsomes and light SPMs) have apparent molecular weights of 330,000 to 310,000 , clearly different from any of the major glycoproteins present in the other vertebrates. Although the other groups of Con A-binding glycoproteins also appear to be present in shark brain, they only represent a minor proportion of the total Con A binding capacity (Fig. 3).

Similar observations apply to antigen PSD-95. It is present in all species, and in all cases, it is found highly enriched in the junctions. However, its molecular weight has suffered slight or, in shark, considerable changes. The detailed structure of the antigenic determinants also must have undergone modifications, because the amount of antibody binding decreases as the species become more separated from mammals (Table VI).

Antigen PSD-95 as a specific marker for synaptic junctions. The restricted location of PSD-95 makes this protein an adequate marker to estimate the content of PSDs (and, hence, SJs) in any given subcellular fraction. The amount of antibody binding to PSD-95 in mitochondrial fractions has been used to determine the extent of contamination of this fraction by PSD material. The agreement of this estimate and independent determinations encourage us to believe that PSD-95 can be used for the quick characterization of junctional fractions in 
those instances, such as in developing organisms, where buoyant density distribution is not definite evidence of identity. It also should permit the study of problems involving synaptogenesis at the immunohistochemical and biochemical level in a variety of organisms.

\section{References}

Adair, W. S., D. Jurivich, and V. W. Goodenough (1978) Localization of cellular antigens in sodium dodecyl sulphate-polyacrylamide gels. J. Cell Biol. 79: 281-285.

Baudry, M., M. C. Bundman, E. K. Smith, and G. Lynch (1981) Micromolar levels of calcium stimulate proteolytic activity and glutamate receptor binding in rat brain synaptic membranes. Science 212: 937-938.

Beach, R. L., P. T. Kelly, J. A. Babitch, and C. W. Cotman (1981) Identification of myosin in isolated synaptic junctions. Brain Res. 225: 75-93.

Bittiger, H., and H. P. Schnebli (1974) Binding of concanavalin $A$ and ricin to synaptic junctions of rat brain. Nature 249: 370-371.

Blitz, A. I., and R. F. Fine (1974) Muscle-like contractile proteins and tubulin in synaptosomes. Proc. Natl. Acad. Sci. U. S. A. 71 : $4472-4476$.

Blomberg, F., R. S. Cohen, and P. Siekevitz (1977) The structure of postsynaptic densities isolated from dog cerebral cortex. II. Characterization and arrangement of some of the major proteins within the structure. J. Cell Biol. 74: 204-225.

Brown, W. R. A., A. N. Barclay, C. A. Sunderland, and A. F. Willians (1981) Identification of a glycophorin-like molecule at the cell surface of rat thymocytes. Nature 289: 456-460.

Burridge, K., and D. Bray (1975) Purification and structural analysis of myosins from brain and other non-muscle tissues. J. Mol. Biol. 99: 1-14.

Churchill, L., C. W. Cotman, G. Banker, P. Kelly, and L. Shannon (1976) Carbohydrate composition of central nervous system synapses. Analysis of isolated synaptic junctional complexes and postsynaptic densities. Biochim. Biophys. Acta 448: 57-72.

Cohen, R. S., and P. Siekevitz (1978) Form of the postsynaptic density. A serial section study. J. Cell Biol. 78: 36-46.

Cohen, R. S., F. Blomberg, and P. Siekevitz (1976) Studies of postsynaptic densities isolated from dog cerebral cortex. J. Cell Biol. 70: 93a.

Cohen, R. S., F. Blomberg, K. Berzins, and P. Siekovitz (1977) The structure of postsynaptic densities isolated from dog cerebral cortex. I. Overall morphology and protein composition. J. Cell Biol. 74: 181-203.

Cotman, C. W., and P. T. Kelly (1980) Macromolecular architecture of CNS synapses. In The Cell Surface and Neuronal Function, C. W. Cotman, G. Poste, and G. L. Nicholson, eds., pp. 505-533, Elsevier/North Holland Biomedical Press, New York.

Cotman, C. W., and D. Taylor (1972) Isolation and structural studies on synaptic complexes from rat brain. J. Cell Biol. 55: 696-711.

Cotman, C. W., and D. Taylor (1974) Localization and characterization of concanavalin A receptors in the synaptic cleft. J. Cell Biol. 62: 236-242.

Cotman, C. W., G. Banker, L. Churchill, and D. Taylor (1974) Isolation of postsynaptic densities from rat brain. J. Cell Biol. 63: 441-455.

Craig, S. W., and C. L. Lancashire (1980) Comparison of intestinal brush-border $95-\mathrm{kDalton}$ polypeptide and alpha-actinins. J. Cell Biol. 84: 655-667.

Creutz, C. E. (1977) Isolation, characterization and localization of bovine adrenal medullary myosin. Cell Tissue Res. 178: 17-38.
Davis, G. A., and F. E. Bloom (1973) Isolation of synaptic junctional complexes from rat brain. Brain Res. 62: 135-153. Edds, M. W., Jr., G. E. Schneider, R. M. Gaze, and L. N. Irwin, eds. (1979) Specificity and plasticity of retinotectal connections. Neurosci. Res. Program Bull. 17: No. 2.

Feit, H., P. T. Kelly, and C. W. Cotman (1977) Identification of a protein related to tubulin in the postsynaptic density. Proc. Natl. Acad. Sci. U. S. A. 74: 1047-1051.

Foster, A. C., E. E. Mena, D. T. Monaghan, and C. W. Cotman (1981) Synaptic localization of kainic acid binding sites. Nature 289: 73-74.

Goodrum, J. F., and R. Tanaka (1978) Protein and glycoprotein composition of subsynaptosomal fractions. Implications for exocytosis and recycling of synaptic vesicles. Neurochem. Res. 3: 599-617.

Grab, D. J., K. Berzins, R. S. Cohen, and P. Siekevitz (1979) Presence of calmodulin in postsynaptic densities isolated from canine cerebral cortex. J. Biol. Chem. 254: 8690-8696.

Grab, D. J., R. K. Carlin, and P. Siekevitz (1980) The presence and functions of calmodulin in the postsynaptic density. Ann. N. Y. Acad. Sci. 356: 55-72.

Gurd, J. W. (1977a) Identification of lectin receptors associated with rat brain postsynaptic densities. Brain Res. 126: 154159.

Gurd, J. W. (1977b) Synaptic plasma membrane glycoproteins: Molecular identification of lectin receptors. Biochemistry 16 : 369-374.

Horder, T. J., and K. A. C. Martin (1978) Morphogenetics as an alternative to chemospecificity in the formation of nerve connections. Soc. Exp. Biol. Symp. 32: 275-358.

Jacobson, M. (1978) Developmental Neurobiology, Plenum Press, New York.

Kelly, P. T., and C. W. Cotman (1977) Identification of glycoproteins and proteins at synapses in the central nervous system. J. Biol. Chem. 252: 786-793.

Kelly, P. T., and C. W. Cotman (1978) Synaptic proteins. Characterization of tubulin and actin and identification of a distinct postsynaptic density polypeptide. J. Cell Biol. 79: 173-183.

Kelly, P. T., and M. W. Luttges (1975) Electrophoretic separation of nervous system proteins on exponential gradient polyacrylamide gels. J. Neurochem. 24: 1077-1079.

Kelly, P., C. W. Cotman, C. Gentry, and G. L. Nicolson (1976) Distribution and mobility of lectin receptors on synaptic membranes of identified neurons in the central nervous system. J. Cell Biol. 71: 487-496.

Klee, C. B., T. H. Crouch, and M. H. Krinks (1979) Calcineurin: $A$ calcium and calmodulin binding protein of the nervous system. Proc. Natl. Acad. Sci. U. S. A. 76: 6270-6273.

Korn, E. D. (1978) Biochemistry of actomyosin-dependent cell motility. Proc. Natl. Acad. Sci. U. S. A. 75: 588-599.

Laemmli, U. K. (1970) Cleavage of structural proteins during the assembly of the head of bacteriophage 'I4. Nature 227: 680-685.

Lee, K. S., F. Schottler, M. Oliver, and G. Lynch (1980) Brief bursts of high-frequency stimulation produce two types of structural change in rat hippocampus. J. Neurophysiol. 44: 247-258.

Levine, J., and M. Willard (1981) Fodrin: Axonally transported polypeptides associated with the internal periphery of many cells. J. Cell Biol. 90: 631-643.

Lowry, O. H., N. J. Rosebrough, A. L. Farr, and R. J. Randall (1951) Protein measurement with the Folin phenol reagent. J. Biol. Chem. 193: 265-275.

Lund, R. D. (1978) Development and Plasticity of the Brain, Oxford University Press, New York.

Mahendran, C., and S. Berl (1979) Resolution of brain troponin complex. J. Neurochem. 33: 149-157. 
Mahler, H. R. (1977) Proteins of the synaptic membrane. Neurochem. Res. 2: 119-147.

Matus, A. (1978) Synaptic membranes and junctions from brain. In Methods in Membrane Biology, E. D. Korn, ed., Vol. 9, pp. 203-236, Plenum Press, New York.

Matus, A. (1981) 'The postsynaptic density. Trends Neurosci. 4: 51-53.

Matus, A. I., and D. H. Taff-Jones (1978) Morphology and molecular composition of isolated postsynaptic junctional structures. Proc. R. Soc. Lond. (Biol.) 203: 135-151.

Matus, A., S. de Petris, and M. C. Raff (1973) Mobility of concanavalin A receptors in myelin and synaptic membranes. Nature New Biol. 244: 278-279.

Matus, A., G. Pehling, M. Ackermann, and J. Malder (1980) Brain postsynaptic densities: Their relationship to glial and neuronal filaments. J. Cell Biol. 87: 346-359.

Matus, A., R. Bernhardt, and H. Taff-Jones (1981) High molecular weight microtubule-associated proteins are preferentially associated with dendritic microtubules in brain. Proc. Natl. Acad. Sci. U. S. A. 78: 3010-3014.

Nieto-Sampedro, M., C. M. Bussineau, and C. W. Cotman (1981a) Optimal concentration of iodonitrotetrazolium for the isolation of junctional fractions from rat brain. Neurochem. Res. 6: 307-320.

Nieto-Sampedro, M., C. M. Bussineau, and C. W. Cotman (1981b) Postsynaptic density antigens. Preparation and characterization of an antiserum against postsynaptic densities. J. Cell Biol. 90: 675-686.

Peters, A., and I. R. Kaisermann-Abramof (1969) The small pyramidal neuron of the rat cerebral cortex. The synapses upon dendritic spines. Z. Zellforsch. Mikrosk. Anat. 100: 487506.

Puszkin, S., and S. Kochwa (1974) Regulation of neurotrans- mitter release by a complex of actin with relaxing protein isolated from rat brain synaptosomes. J. Biol. Chem. 249 . 7711-7714.

Rostas, J. A. P., P. T. Kelly, and C. W. Cotman (1977) The identification of membrane glyco-components in polyacrylamide gels: A rapid method using $\left({ }^{125} \mathrm{I}\right)$ labelled lectins. Anal. Biochem. 80: 366-372.

Rostas, J. A. P., P. T. Kelly, R. H. Pessin, and C. W. Cotman (1979) Protein and glycoprotein composition of synaptic junctions prepared from discrete synaptic regions and different species. Brain Res. 168: 151-167.

Schook, W., C. Ores, and S. Puszkin (1978) Isolation and properties of brain alpha-actinin. Biochem. J. 175: 63-72.

Therien, H. M., and W. E. Mushynski (1976) Isolation of synaptic junctional complexes of high structural integrity from rat brain. J. Cell Biol. 71: 807-822.

Trifaró, J. M. (1978) Contractile proteins in tissues originating in the neural crest. Neuroscience 3: 1-24.

Walters, B. B., and A. I. Matus (1975) Tubulin in the postsynaptic junctional lattice. Nature 257: 496-498.

Wang, Y. -J., and H. R. Mahler (1976) Topography of the synaptosomal membrane. J. Cell Biol. 71: 639-658.

Willard, M. (1977) The identification of two intra-axonally transported polypeptides resembling myosin in some respects in the rabbit visual system. J. Cell Biol. 75: 1-11.

Willard, M., W. M. Cowan, and P. R. Vagelos (1974) The polypeptide composition of intra-axonally transported proteins: Evidence for four transport velocities. Proc. Natl. Acad. Sci. U. S. A. 71: 2183-2187.

Wood, J. G., R. W. Wallace, J. N. Whitaker, and W. Y. Cheung (1980) Immunocytochemical localization of calmodulin and a heat-labile calmodulin-binding protein (CA M-BP $\left.\mathrm{BP}_{80}\right)$ in basal ganglia of mouse brain. J. Cell Biol. 84: 66-76. 